Section G : Brig.-Gen. C. H. Mitchell ; Dr. Elihu Thomson, Lynn, Mass.

Section $H$ : Dr. R. Broom, Douglas, S. Africa ; Dr. H. C. van Riet Lowe, Cape Town ; Prof. Sergio Sergi, Rome ; Prof. V. Suk, Brno; Dr. G. Thilenius, Hamburg.

Section I: Prof. Frank Allen, Manitoba; Dr. R. Alexander, Pretoria; Prof. D. W. Bronk, Pennsylvania ; Dr. C. K. Drinker, Harvard ; Prof. Yandell Henderson, Yale; Prof. C. Heymans, Ghent ; Dr. J. M. Rivers, New York.

Section $J$ : Prof. W. Köhler, Berlin; Prof. H. Piéron, Paris.

Section K: Prof. F. E. Lloyd, Montreal.

Section L: Prof. F. Clarke, Montreal ; the Hon.

S. Rivers Smith, Tanganyika.

Section $M$ : Dr. W. Lawrence Balls, Giza; Dr. D. J. Hissink, Groningen.
Among other visitors from abroad whose names do not appear in the handbook and time-table of the sectional meetings, but who will probably take part in some of the proceedings, we notice the following: Dr. C. G. Abbot, Washington; Prof. Max Bodenstein, Berlin; Prof. Niels Bohr, Copenhagen; Prof. A. H. R. Buller, Manitoba; Dr. J. McKeen Cattell, New York; Prof. R. Chodat, Geneva; Prof. E. J. Cohen, Utrecht ; Prince Conti, Florence; Baron de Geer, Gothenburg; Prof. W. K. Gregory, New York; Prof. W. Heisenberg, Leipzig ; Prof. G. Hevesy, Freiburg ; Prof. A. E. Kennelly, Harvard; Prof. J. P. Lotsy, Velp ; Prof. A. B. Macallum, London, Ont.; Senatore Marconi, Rome ; Prof. R. A. Millikan, Pasadena; Dr. Th. Mortensen, Copenhagen; Dr. H. Nagaoka, Tokyo; Prof. J. Perrin, Paris ; Dr. H. M. Tory, Ottawa ; Prof. R. Willstätter, Munich ; Prof. R. W. Wood, Baltimore.

\title{
International Union of Physics, Brussels Meeting, I93I.
}

\begin{abstract}
A MEETING of the International Union of A Physics was held in Brussels on July 12, and was attended by representatives of about fourteen countries. Prof. Gerlach, of Munich, and Dr. Rupp, of Berlin, were also present by the invitation of the president. A revised set of statutes, prepared by the executive committee, was considered and passed.
\end{abstract}

At the previous meeting of the Union an invitation had been given to hold a meeting in England so soon as it was possible for all nations to take part. Sir Richard Glazebrook, as representing Great Britain, expressed his pleasure that, under the new statutes, this condition was now satisfied, and cordially welcomed the German visitors to the meeting. He then renewed the British invitation, saying, however, that he had been informed that there was a very strong desire that the Union should visit America on the occasion of the Chicago Exhibition in 1933, and that it was for the Union to decide. A telegram was then read from Prof. Millikan, cordially inviting the Union, and this invitation was strongly supported by Dr. Kennelly and Dr. Schlesinger, the American delegates.

After some further discussion, the General Assembly of the Union decided unanimously to accept the invitation to Chicago, and to invite Prof. Millikan to become president of the Union in succession to Sir William Bragg, whose term of office had expired.

Discussion then followed on matters brought forward either by national committees or by individual physicists. Among these were the pro- posals of the British National Committee as to the definition of the calorie and a name for the unit of thermal conductivity, and of M. Cotton as to names for magnetic units. As the result of the discussion, a sub-committee was appointed to deal with symbols, units, and nomenclature in physics and to repnrt to the General Assembly. At the first meeting of this sub-committee, held on July 12, Prof. Kennelly in the chair, the following resolution was agreed to unanimously :

That this Commission recommends to the Executive Committee of the International Union of Physics that the following two propositions be communicated to the next General Assembly as recommendations from this Commission.

1. That the Unit of Heat when measured in units of energy be the Joule, defined as equivalent to $10^{7}$ ergs.

2. That the gramme-calorie is the amount of heat required to raise the temperature of one gramme of water from $14 \cdot 5^{\circ}$ to $15 \cdot 5^{\circ}$ of the International Scale of Temperature.

Note on Proposition 2.

"According to existing measurements, the gramme calorie is equivalent to

$$
4 \cdot 18_{6} \text { Joules. }
$$

"The definition is consistent with the decision of the International Steam Tables Conference in 1929 to adopt as a unit suitable for their purpose an International Kilocalorie equivalent to $1 / 860$ of an International Kilowatt Hour, the difference being that between the Absolute Watt* and the International Watt."

* International Watt $=1 \cdot 00039$ Absolute Watts.

\section{Obituary.}

Sir Thomas Stanton, C.B.E., F.R.S.

$\mathrm{T}$ HE death at Pevensey Bay on Aug. 30 of Sir Thomas Ernest Stanton tragically ended a distinguished career largely devoted to the service of the State. He was one of the greatest research engineers Great Britain has produced, and a worker whose name will rank with those of Rankine and Osborne Reynolds, under the latter of whom he studied and carried out some of his early work.

Sir Thomas, who was sixty-five years of age, had retired in December 1930 from the post of superintendent of the Engineering Department at the

No. 3229, VoL. 128] 
National Physical Laboratory at Teddington, a position he had occupied for nearly thirty years. Born on Dec. 12, 1865, the son of Thomas Stanton of Atherstone, he was educated at Atherstone and Manchester Grammar Schools, whence he proceeded to Owens College, where, after experience with Messrs. Gimson and Co., engineers, of Leicester, he was appointed demonstrator by Osborne Reynolds in the Whitworth Laboratory, a position he held for five years.

In 1896, Stanton removed to Liverpool, on appointment to the senior lectureship in engineering at University College. Three years later he became professor of civil and mechanical engineering at Bristol, a position he held until 1901, when he joined the staff of the National Physical Laboratory, which was then in the earliest stages of its development.

Stanton proceeded to build up the Engineering Department to its present position of eminence. Few have exerted a wider influence in the application of laboratory methods to engineering problems. For some years he was also in charge of the aerodynamical work of the Laboratory. His personal researches covered an extensive field, including the study of wind pressures on structures, the resistance of materials to intermittent stresses, lubrication, the heat-transfer and friction between solid surfaces and moving fluids, and the movement of projectiles at speeds exceeding the velocity of sound. These and other researches have formed the subject of numerous papers presented during the past thirty years to the Royal Society, the Institution of Civil and Mechanical Engineers, and the more important engineering journals. His book on "Friction" (1923) is also very widely known. So recently as May last he delivered the thirty-seventh Sir James Forrest Lecture, on " Engineering Research," before the Institution of Civil Engineers.

Stanton was admitted a fellow of the Royal Society in 1914 and served on the Council during 1927-29. $\mathrm{He}$ was a D.Sc. of the University of Manchester, a fellow of the Royal Aeronautical Society, and a member of the Institutions of Civil and Mechanical Engineers. For his work in the War he received the C.B.E. in 1920 and he was knighted in 1928.

Despite a somewhat retiring disposition, Stanton's advice was much sought, for it was known to be kindly, sound, and sagacious. He was genial and unassuming, and his popularity with his colleagues was amply evinced on the occasion of his retirement from the Laboratory. During the past year his life had been clouded by ill-health. He married in 1912 a daughter of Mr. John Child, of London, and he leaves, besides Lady Stanton, a daughter aged eighteen years and a fourteen-year-old son, to whom we offer our deep sympathy.

\section{Dr. L. W. Sambon.}

IT is with deep regret that we have to record the sudden death of Dr. L. W. Sambon in Paris on Aug. 31. By his death a striking personality has passed away.

No. 3229, Vor. 128]
Sambon was born in Italy in November 1865. He was of Anglo-French parentage, his father being Comm. Jules Sambon, an antiquarian and numismatist of repute, and his mother an Englishwoman. He was educated in England and Switzerland, and later studied medicine at St. Bartholomew's Hospital Medical School and in the University of Naples, where he took his medical degree.

From an early age Sambon took great interest in numismatics, archæology, natural history, and volcanology. As a medical student, he rendered valuable service during the great cholera epidemic in 1884, and was awarded for his work bronze and gold medals by the Italian and French Governments. In 1897 he settled in London, where he devoted himself to medical research at a time when tropical medicine was almost in its infancy. His first article on "Acclimatisation of the White Man in Tropical Lands " roused a great deal of controversy, but it had a good effect. It brought him in contact with Manson, who was at that time Medical Adviser to the Colonial Office, and their association was interrupted only by the death of Manson.

In the summer of 1900 , Sambon carried out the now classical malarial experiment in the Roman Campagna (Ostia) with Dr. George C. Low and one of us (T.).

Sambon was for many years a lecturer at the London School of Tropical Medicine. He published many papers on sunstroke, blackwater fever, malaria, sleeping sickness, pellagra, typhoid, schistosomiasis, and so on. He was at the time of his death carrying out investigations on cancer, in Westmoreland - a subject on which he had already published several reports. He wrote much on the history of medicine. He studied the surgical instruments of ancient times and utensils found in Roman graves, and his interpretations of these relics have thrown considerable light on the medical knowledge of past ages.

Sambon has been called volcanic, he has been accused of being a dreamer and a visionary, but whatever theories he may have advanced, which may have been at the time considered far-fetched, those theories undoubtedly fertilised the fields in which he worked.

\section{A. J. Engel Terzi. S. Maulik.}

WE regret to announce the following deaths:

Dr. Aristides Agramonte, president-elect of the Pan-American Medical Congress, known for his work on bacteriology in Cuba, who associated himself with the work of clearing the Panama Canal zone of disease, aged sixty-two years.

Prof. Errol Lionel Fox, professor of chemistry at Washington College, Chesterton, Maryland, on July 17, aged thirty-eight years.

Dr. Russell A. Oakley, principal agronomist in the Division of Forage Crops and Diseases of the Bureau of Plant Industry, United States Department of Agriculture, on Aug. 6, aged fifty-one years. 